\title{
A survey on endophytic fungi within roots of Chenopodiaceae species under different environmental conditions
}

\author{
Aletaha $\mathbf{R}^{1, *}$, Safari Sinegani $\mathbf{A A}^{1}{ }^{1}$, Zafari $\mathrm{D}^{\mathbf{2}}$ \\ ${ }^{1}$ Department of soil science, College of Agriculture, Bu-Ali Sina University, Hamadan, Iran \\ ${ }^{2}$ Department of Plant Protection, college of Agriculture, Bu-Ali Sina University, Hamadan, Iran
}

Aletaha R, Safari Sinegani AA, Zafari D 2018 - A survey on the endophytic fungi in the roots of Chenopodiaceae under different environmental conditions. Mycosphere 9(4), 618-634, Doi 10.5943/mycosphere/9/4/1

\begin{abstract}
Iran with large saline areas is an ideal habitat for growth of plants of the family Chenopodiaceae. Diversity, frequency, and population density of endophyte fungi species depend on the edaphic and climatic conditions, heterogeneity of habitats and niches present within the host tissues, as well as on the competing organisms. In order to isolate endophytic fungi, 52 specimens of each Chenopodiaceae species were collected from its natural habitats in dry and temperate ecosystems located in the south and north of Iran. Staining roots showed that hyphae, spore and microsclerotia of endophytes are present in all surveyed roots. After surface disinfection, specimens were cultured on potato dextrose agar medium (PDA). A total of 192 fungal isolates were obtained and identified on the basis of morphological features and molecular identification. Obtained isolates consisted of eight dematiaceous genera (Alternaria, Bipolaris, Chaetomium, Cladosporium, Curvularia, Embellisia, Macrophomina and Ulocladium) and four non dematiaceous genera (Acremonium, Aspergillus, Fusarium and Penicillium) and twelve types of sterile mycelia. We isolated three species of Alternaria in the studied sites that base on phylogenetic studies located in three different groups. Most of plant roots had a colonization rate of $100 \%$ in dry ecosystems (site A, B), while the average colonization rate in temperate ecosystem was $63.8 \%$. However, Shannon's and Fisher's Alpha indices indicate diversity of fungi in temperate ecosystem (site C, 2.45) is higher than that of in other sites. Among the genera, Fusarium was the most abundant in all ecosystems (site A 51\%, site B 49\% and site C 57\%). Climate and soil condition can alter frequency of endophytic fungi in each ecosystem, so that site $\mathrm{C}$ with different altitude and soil condition in temperate region had different fungal distribution patterns compared to other studied sites in arid region. Our observations showed that higher endophytic fungi frequency can occur in the roots of plant in arid soils with $\mathrm{pH}$ values ranging from 7 to 8 and $\mathrm{EC}$ values ranging from $1.4-4.5\left(\mathrm{dS} \mathrm{m}^{-1}\right)$ in high altitude (1230-2000 m) compared to those in roots of plants in temperate soil in low altitude (13m). According to similarly Jaccard index, site A and B had the highest similarity (0.26).
\end{abstract}

Keywords - Arid environment - Soil condition - Temperate environment

\section{Introduction}

The term "endophyte" was coined by De Bary in 1866 to distinguish organisms that live within internal host plant from "epiphytes", living on outer surface of plants (Sieber 2007, Hyde \& Soytong 2008). Symbiosis between fungi and leaves or needles is sometimes termed "mycophylla" 
(Sieber 2007). According to differences in taxonomy, plant species and functions, two groups of endophytic fungi are distinguished, clavicipitalean (C) and non-clavicipitalean (NC) endophytes (Stone et al. 2004). Clavicipitalean endophytes typically refer to clavicipitaceous species and a small number of ascomycetes endophytes (Eshel \& Beeckman 2013). Generally, C endophytes colonize plant shoots and have perennial systemic intercellular infections throughout the entire life cycle of the host (Rodriguez et al. 2008). Species of the $\mathrm{C}$ endophytes form symbioses almost exclusively with cool-season C3 grasses and warm-season C4 grasses. They are vertically transmitted by seeds to the next host generation. Alkaloids are secondary metabolites that produce by $\mathrm{C}$-endophytes. In addition, alkaloids can protection of plant against insects and herbivores, disease resistance and stress tolerance (Purahong \& Hyde 2011). In contrast, nonclavicipitalean endophytes are comprise Dikarya members (Ascomycota or Basidiomycota) (Rodriguez et al. 2009). Non-clavicipitalean endophytes form asystematic symbiosis with all plant species of nonvascular to vascular plants (Sieber 2007, Hyde \& Soytong 2008). Unlike C-endophytes, NCendophytes establish mutualisms with root, shoot and rhizome. Members of NC-endophytes divided into three subgroups basis on ecological interactions, biodiversity and other features (Purahong \& Hyde 2011). NC-endophytes enhance host growth and host yield by the facilitates mineral nutrient uptake, utilization of organic nutrient pool, and water uptake (Eshel \& Beeckman 2013). All of endophytes are important source for bioactive antimicrobial compounds, used in agriculture, commercial industry and in medicine (Schulz et al. 2002). C-endophytes fungi have different life styles from mutualism to parasitism, and the NC-endophytes have life styles from mutualism to saprotrophic (Rodriguez et al. 2009). The symbiosis type may change over time and space. Some endophytic fungi swich to saprotroph fungi. This phenomenon confirmed by use of ribosomal DNA-based sequence study that showed phylogenetic data of endophytic fungi conformed with morphological studies of saprotrophic fungi (Promputtha et al. 2007). Differences in chemical and physical properties of soil, climate changing, quality of litters and other microenvironment interaction can change microorganisms communities including potential root endophytes (Sieber \& Grünig 2006). However, the roots of all vascular plants host a great variety of fungi. Previous studies have isolated endophytic fungi from numerous plants worldwide in different climate with molecular data, e.g. palms (Guo et al. 2001), Pinus (Guo et al. 2003), Magnolia liliifera (Promputtha et al. 2005), Atriplex canescens (Lucero et al. 2011) and grasses (Purahong et al. 2010). In Iran, Thymus, a medicinal plant in Lamiaceae was sampled from western Iran and obtained eleven different genera including: Alternaria, Aspergillus, Cladosporium, Colletotrichum, Curvularia, Cylindrocarpon, Drechslera, Fusarium, Phoma, Stemphylium and Ulocladium (Masumi et al. 2015). To isolate endophytic fungi, surface sterilization and the sample size are very important. Low degree of sterilization and high sample size will result to detection of more species. In the study of 17 different species root, only five species (Alternaria sp., Cochliobolus sp., Penicillium sp., Phoma medicaginis and a Xylariaceae species was isolated in Mexico (Rivera-Orduña et al. 2011).

In Iran, saline desert soils have surface area of almost 1,648,000 $\mathrm{Km}^{2}$ (Akhani 2006). Some saline areas were reported as well as Chenopodiaceae species vegetation, for example, the Urmia shore; Kavire Meyghan; south of Delijan; and the Shurtangeh in northwest of Damghan (Akhani 2006). Large areas of salinity are located in central Iran such as "Kavire Lut" and "Dashte Kavir" (Akhani 2011). Iran with large saline areas is a typical habitat of Chenopodiaceae family with 139 species, followed by the Poaceae (35), Tamaricaceae (29), Asteraceae (23) and Plumbaginaceae (14). Therefore, Chenopodiaceae has become a dominate plant species in deserts of Iran. Chenopodiaceae is an important component of the flora and vegetation of the arid and semiarid regions of the world. This family includes ca. 100 genera and 1400 species. A great number of the halophytes and xerohalophytes of the world are the members of this family. Investigation of endophytic fungi in six halophyte plants including three species of Chenopodiaceae (Kochia, Suaeda australis, Suaeda japonica) showed various species of fungi such as Acremonium, Alternaria, Capnodiales, Cladosporium, Fusarium and Penicillum. The genus Fusarium and Penicillum were the most frequency in examined plants (You et al. 2012). In other research, root, 
stem and leaf of some Chenopodiaceae species (Salsola, Suaeda, Coriospermum and Bassia) were dominated by high colonization of fungi but by low diversity of isolate species in three deserts of China (Sun et al. 2012). Similarity indices (Jaccard, Sorensen and Bray-Curtis) were low between part of plants and deserts (Sun et al. 2012).

There are many investigations on endophytic fungi in woody and herbaceous plants and some of Chenopodiaceae species (Petrini 1991, Stone et al. 2004, Upson et al. 2009, Lv et al. 2010). Our knowledge of, endophytic fungi in Chenopodiaceae species have not been investigated in Iran. Despite of abundance of halophytic vegetation in Iran, there is still a conspicuous gap in our understanding of their endophytic fungi. The objectives of the present study were 1) To isolate and identify of endophytic fungi in Chenopodiaceae species in temperate and arid regions of Iran 2) To study the difference among endophytic fungi frequency in plant species in temperate and arid ecosystems of Iran and 3) To study the importance of the main climatic factors (temperature, rain fall, altitude, controlling soil condition) on diversity and frequency of endophytic fungi.

\section{Materials \& Methods}

\section{Study sites and sample collection}

The plant samples were collected in August 2015 from three sites. Fourteen species of Chenopodiaceae were collected from site A: Dasht-e Javar (latitude $31^{\circ}, 21^{\prime}$ and longitude $56^{\circ}, 17^{\prime}$ ), from the Kouhbanan region in Kerman Province of southeastern Iran. Kerman is located in margin of the Lut Desert (Kavir-e Lut) with mean annual temperature and precipitation being $15{ }^{\circ} \mathrm{C}$ and 150 $\mathrm{mm}$, respectively. This region is located at an altitude 2,000 $\mathrm{m}$ above sea level. Thirty species of Chenopodiaceae were collected from Site B: Kavir-e Yazd (latitude $31^{\circ}, 43^{\prime}$ and longitude $54^{\circ}, 04^{\prime}$ ) with mean annual temperature and precipitation being $19^{\circ} \mathrm{C}$ and $62 \mathrm{~mm}$, respectively. This region is located at an altitude $1230 \mathrm{~m}$ above sea level. Eleven species of Chenopodiaceae were collected from Site C: Khalij-e Gorgan (latitude $36^{\circ}, 46^{\prime}$ and longitude $53^{\circ}, 40^{\prime}$ ), is located in the southeastern Caspian Sea in Mazandaran province, north of Iran. Its mean annual temperature and precipitation are $17^{\circ} \mathrm{C}$ and $622 \mathrm{~mm}$, respectively. This region has an altitude of $13 \mathrm{~m}$ above sea level (Fig.1). Soil organic carbon was determined using wet digestion procedure. Soil texture was determined by hydrometer method. As well soil $\mathrm{pH}$ and EC were determined in a 1:2 soil-solution ratio using a combination electrode and electrical conductivity meter (Van Reeuwijk 1993).

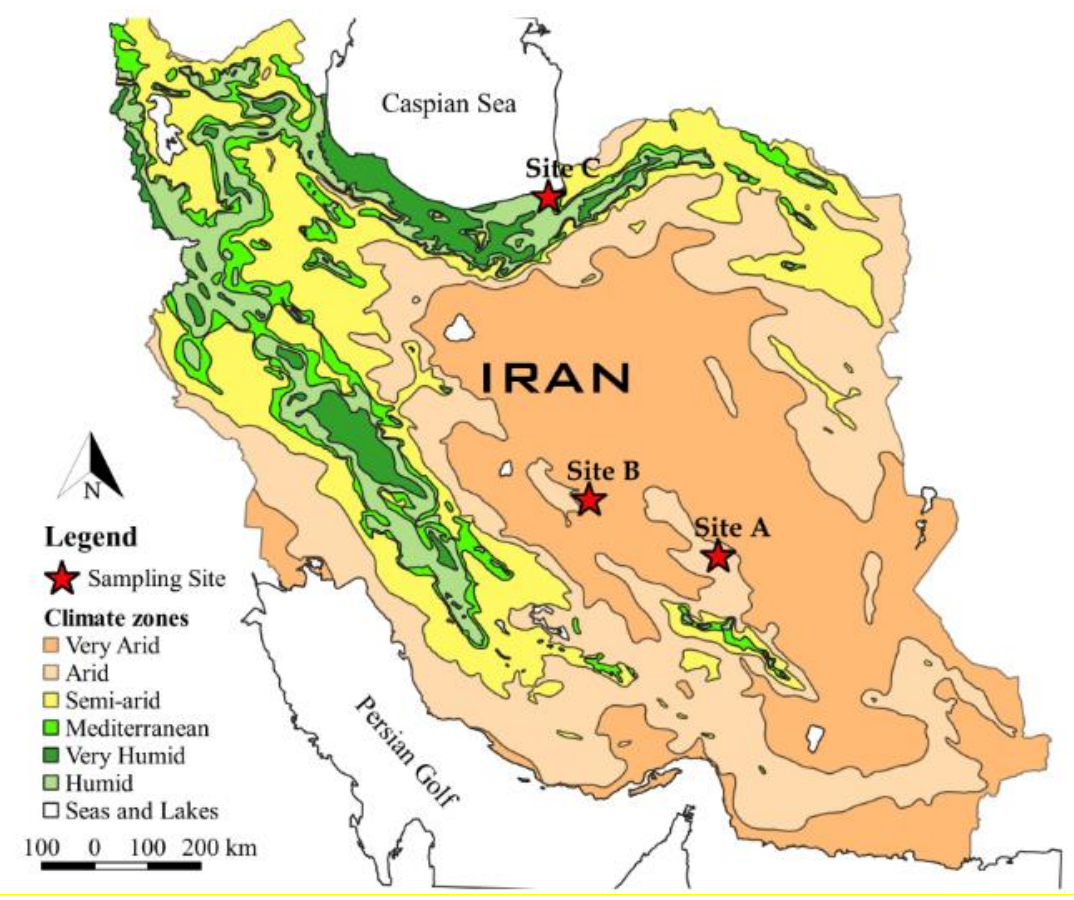

Figure 1 - Sampling sites: site A in southeast, site B in central and site C in north of Iran. 


\section{Staining, isolation and identification of endophytic fungi}

Plants were transferred to laboratory in pots. The roots were washed by tap water to remove the soil. In order to staining and observation of fungus, the cleaned roots were stained by staining method modified by Barrow \& Aaltonen (2001). Segments of the roots were randomly selected and cleared and then placed in $2.5 \% \mathrm{KOH}$ at $100^{\circ} \mathrm{C}$ temperature for $5 \mathrm{~min}$. The roots were rinsed in tap water, bleached with $10 \%$ alkaline $\mathrm{H}_{2} \mathrm{O}_{2}$ for 10 min to remove pigmentation, and placed in $1 \% \mathrm{HCl}$ for $3 \mathrm{~min}$. The decolorized roots were rinsed in tap water, and each sample was placed in trypan blue $\left(0.5 \mathrm{~g}\right.$ trypan blue in $500 \mathrm{~mL}$ glycerol, $450 \mathrm{~mL}$ deionized $\mathrm{H}_{2} \mathrm{O}$ and $\left.50 \mathrm{~mL} \mathrm{HCl}\right)$ and all were autoclaved at $121^{\circ} \mathrm{C}$ for $3 \mathrm{~min}$ and stored in acidic glycerol $\left(500 \mathrm{~mL}\right.$ glycerol, $450 \mathrm{~mL} \mathrm{H}_{2} 0$ and $50 \mathrm{~mL} \mathrm{HCl})$. Ten segments of the stained root $(1 \mathrm{~cm})$ were placed on microscope slides in a drop of permanent mounting stain. A cover slip was placed over the root segment sand observed with a Zeiss Axiophot microscope using both conventional and DIC optics at $\times 100$ magnification. Estimation of colonization rate (percentage) was defined as the ratio between root fragments colonized by mycelium of endophytic fungi and total number of analyzed root fragments multiplied by100 (Sharma \& Jha 2017). For isolation of fungi, the sampled roots were surface sterilized according the protocols described by Hamim et al. (2017). From each bulked sample, healthy feeder roots of uniform maturity and appearance (approximately $0.25 \mathrm{~mm}$ in diameter) were randomly selected and processed in $95 \%$ ethanol for 60 s, followed by surface sterilization in $4 \%$ sodium-hypochlorite for $5 \mathrm{~min}$. The samples were washed for 30s in $95 \%$ ethanol and then were plated on potato dextrose agar (PDA). The endophytic fungi grew out of the pieces after 2-8 weeks incubation at $23^{\circ} \mathrm{C}$ in darkness. Identification of the isolates was performed using colony characteristic and morphology features by standard fungal taxonomic manuals. Some of fungi (Alternaria) were investigated by molecular identification using DNA extraction and PCR amplification of their gpd (Glyceraldehyde-3-Phosphate Dehydrogenase) genes in three sites. In order to produce conidia and conidiophores, some isolates (Dematiaceous) were plated on potatocarrot agar (PCA) in glass petri dishes under ambient temperature $\left(20-23^{\circ} \mathrm{C}\right)$ and cool-white fluorescent light above the petri dishes, with an $8 \mathrm{~h}$ on and $16 \mathrm{~h}$ off cycle. Shannon's and Fisher's Alpha indices were used for estimate of fungal diversity among plant species and Jaccard index was used for estimate of similarity between sites.

\section{Results and discussion}

\section{Fungal isolation and staining}

Totally, 192 fungi isolates were obtained as follows: 45 isolates from the site A (Dashte Javar) (Table 1), 112 isolates from site B (Kavire Yazd) (Table 2) and 35 isolates from site C (Khalij-e Gorgan) (Table 3). Isolates were obtained from dematiaceous genera and the nondematiaceous genera. As a result, dematiaceous genera including Alternaria, Bipolaris, Cladosporium, Chaetomium, Curvularia, Embellisia, Macrophomina and Ulocladium and nonDematiaceous genera such as Acremonium, Aspergillus, Fusarium and Penicillium as well as Mycelia sterilia were identified. Except two plant species, arbuscular mycorrhizae structures were not found in the roots of the studied plants. Many researchers believed that the members of the Brassicaceae, Chenopodiaceae and Amaranthaceae family normally do not form associations with AM fungi (Denison et al. 2003). Although these groups of plant are not able to form AM symbiosis, some scientists reported there is AM symbiosis in some Chenopodiaceae species such as Beta vulgaris, Salicornia, Salsola, Chenopodium and Atriplex (Hirrel et al. 1978, Sonjak et al. 2009). In this study, semi- structure of AM was observed in Beta vulgaris and Spinacia oleracea plants (Fig. 2 E, F). Eruca sativa Lam from Brassicaceae family being reported earlier as nonmycorrhizal, was also recognized in our previous study as mycorrhizal plant colonized by VAMF. Arbuscule, vesicle and hyphae of mycorrhiza fungi were found in roots. Root colonization percentage in this plant species reached 62.13. Both types of mycorrhiza symbiosis, paris and arum were observed (Safari \& Elyasi 2017). 
The genera Aspergillus, Chaetomium, Cladosporium and Fusarium have been previously reported as endophytic fungi in Salicornia sp. plant from India (Kannan et al. 2014). The genera of Alternaria, Cephalosporium, Cladosporium, Chaetomium and Fusarium species has been reported as fungi associated with Salsola kali plant (Pugh \& Williams 1968). The fungi species with melanized hyphae were observed in many plant roots (Fig. 2A). These fungi were often related to Ascomycota fungi named dark septate endophyte (DSE) (Fig. 2C). DSE fungi can form mutualistic associations similar to mycorrhizas (Narisawa 2017). Hyaline hyphae and microsclerotia are structures of DSE found in the sample roots (Fig. 2B, D). Similarly, researchers found and reported the hyaline hyphal or melanized structures in plants of rangeland (Barrow \& Aaltonen 2001). The native plant in arid and semi-arid ecosystems can be colonized by DSE. They help plants overcome the severe drought conditions, and improve tolerance to disease and heavy metals (Shen et al. 2015). As mentioned, dark septate endophyte fungi were reported from Atriplex canescens, a native shrub in arid southwestern USA rangelands (Barrow \& Aaltonen 2001). Totally, endophytic fungi specially dark septate endophytes occur in stressed environments where AM fungi do not grow (Newsham 2011). To our best knowledge, this is the first report of the endophytic fungi associated with Chenopodiaceae family from Iran. Salsola yazdiana and Salicornia persica are halophytic endemic species to central and south-west areas of Iran (Akhani 2003).
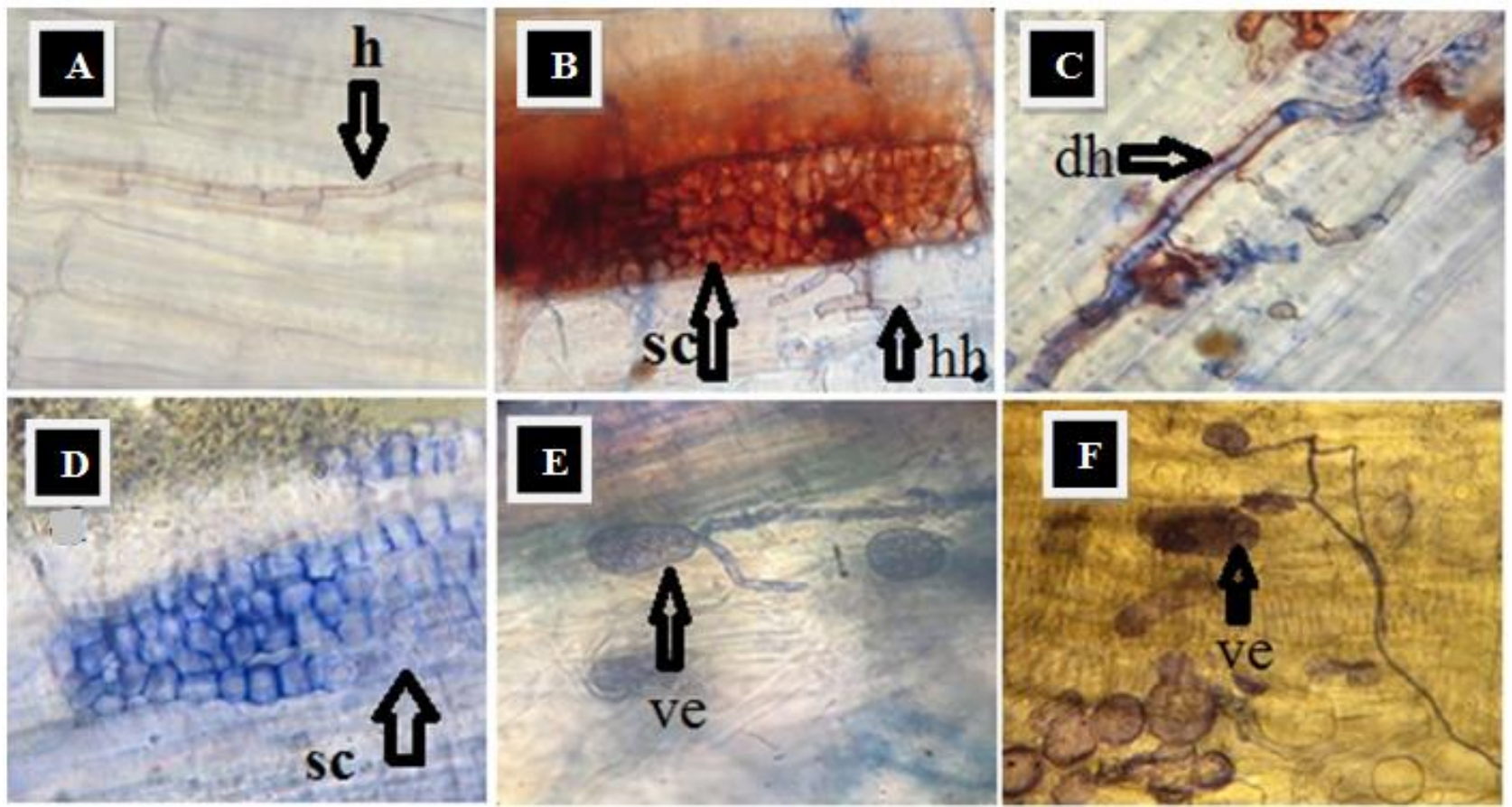

Figure 2 - A-F Endophytes in the roots of Chenopodiaceae family. h: Hyphae growing intercellularly. Sc, hh: Microsclerotia and hyaline septate hypha. dh: Melanized hypha. ve: Vesicles.

\section{Colonization rate and diversity of fungi}

Colonization rate in many species is more than $50 \%$. For example, twelve species out of fourteen plant species $(85.7 \%$ ) have more than $50 \%$ positive detection at Dasht-e Javar (Table 1).

In Site B (Kavir-e Yazd), 27 out of 30 plant species (90\%) have more than $50 \%$ positive detection (Table 2). In contrast, eight out of 11 plant species $(72.7 \%$ ) have more than $50 \%$ positive detection at Khalij-e Gorgan (Site C; Table 3). The highest colonization rate (100\%) was seen in site B (Kavir-e Yazd). The most plant species in Kavir-e Yazd are halophytic genera of Chenopodiacea like Salsola incanescens, Salsola yazdiana, Seidllitzia florida, Salsola tomentosa, Atriplex aucheri, Atriplex leucoclada and kind of Haloxylon and Anabasis. Abundance of endophytic fungi specially DSE has been reported from habitats including arctic, alpine, Antarctic and temperate (Boldt-Burisch \& Naeth 2017). Ascomycota or Basidiomycota endophytes provide 
tolerance to disease and environmental stresses such as $\mathrm{pH}$, temperature, drought or salinity via hormones by stimulation of plant growth (Narisawa et al. 2002, Campanile et al. 2007, Rodriguez et al. 2008). Plants in harsh habitats usually have very high infection frequencies (90-100\%) (Redman et al. 2001, 2002, Rodriguez et al. 2008). Large salty deserts in Kavir-e Yazd can create critical condition for plants. Water and salt stress in this ecosystem is a routine phenomenon. Therefore, plants require an extensive colonization with a great variety of fungi to facilitate nutrient uptake, utilization of organic pools and water uptake. The tree roots in Finland, Germany, and Switzerland colonized by endophytes between $80 \%-100 \%$ depending on the region and up to $70 \%$ are colonized by DSE (Sieber \& Grünig 2013). 90\% of the Norway-spruce roots colonized by DSE (Ahlich et al. 1998). Similarly, root samples from Iva frutescens L. and Triadica sebifera (L.)

Table 1 Fungal taxonomy, number of endophyte isolates, root colonization rate (\%) and Shannon's index in site $\mathrm{A}$ of the studied plant species.

\begin{tabular}{|c|c|c|c|c|}
\hline $\begin{array}{c}\text { Plant species of Site } \\
\text { A(Dasht-e Javar) }\end{array}$ & Fungal taxonomy & $\begin{array}{l}\text { Number } \\
\text { of isolates }\end{array}$ & $\begin{array}{l}\text { Colonization } \\
\text { rate }(\%)\end{array}$ & Shannon's (H) \\
\hline \multirow[t]{2}{*}{ Salsola crassa } & Fusarium sp.6 & 2 & 34 & 0.63 \\
\hline & Rhizoctonia sp. & 1 & & \\
\hline \multirow{2}{*}{ Salsola nitraria } & Fusarium solani & 3 & 96 & 0.67 \\
\hline & Fusarium oxysporum & 2 & & \\
\hline \multirow[t]{2}{*}{ Salsola incanescens } & Aspergillus terreus & 2 & 74 & 0.63 \\
\hline & Fusarium sp.3 & 1 & & \\
\hline \multirow[t]{3}{*}{ Chenopodium album } & Aspergillus sp.2 & 1 & 54 & 1.04 \\
\hline & Fusarium sp.1 & 1 & & \\
\hline & Fusarium sp.2 & 2 & & \\
\hline \multirow{2}{*}{ Atriplex aucheri } & Aspergillus fumigatus & 1 & 88 & 0.63 \\
\hline & Fusarium sp.4 & 2 & & \\
\hline \multirow[t]{3}{*}{ Anabasis aphylla } & Acremonium sp.2 & 1 & 52 & 1.09 \\
\hline & Aspergillus sp.1 & 1 & & \\
\hline & Bipolaris sp. & 1 & & \\
\hline \multirow[t]{3}{*}{ Anabasis setifera } & Aspergillus awamori & 1 & 98 & 1.09 \\
\hline & Aspergillus calidoustus & 1 & & \\
\hline & Rhizoctonia sp. & 1 & & \\
\hline \multirow[t]{2}{*}{ Anabasis аппиа } & Fusarium sp.5 & 2 & 62 & 0.63 \\
\hline & Macrophomina phaseolina & 1 & & \\
\hline \multirow[t]{3}{*}{ Kochia stellaris } & Fusarium sp.1 & 2 & 60 & 1.04 \\
\hline & Rhizoctonia sp. & 1 & & \\
\hline & Penicillium sp. & 1 & & \\
\hline \multirow{2}{*}{ Salsola arbuscula } & Acremonium sp. 1 & 1 & 62 & 0.69 \\
\hline & Rhizoctonia sp. & 1 & & \\
\hline \multirow[t]{2}{*}{ Anabasis setifera } & Fusarium sp.5 & 2 & 90 & 0.69 \\
\hline & Fusarium solani & 2 & & \\
\hline \multirow{2}{*}{ Suaeda aegyptica } & Aspergillus terreus & 2 & 88 & 0.63 \\
\hline & Fusarium sp.6 & 1 & & \\
\hline \multirow[t]{3}{*}{ Salsola crassa } & Fusarium brachygibbosum & 1 & 42 & 1.09 \\
\hline & Rhizoctonia sp. & 1 & & \\
\hline & Penicillium sp. & 1 & & \\
\hline \multirow[t]{2}{*}{ Cornulaca leucacantha } & Alternaria alternate & 1 & 90 & 0.69 \\
\hline & Mycellia sterile & 1 & & \\
\hline
\end{tabular}

Small, collected in Louisiana, USA, illustrated $42 \%$ colonization by DSE (Kandalepas et al. 2010). At the present study, we report $88 \%$ - 100\% colonization by endophytic fungi in Atriplex species (Tables 1, 2, 3) including Aspergillus fumigatus, Aspergillus awamori, Chaetomium sp. Fusarium oxysporum, and Rhizoctonia sp. genera for the first time. Similarly, for the first time in Australia reported seventy- one fungi including Alternaria, Cladosporium, Fusarium, Libertella, Phoma Sporormiella intermedia and variospora from Atriplex (Sieber \& Grünig 2013) and another report of Atriplex endophytic fungi comes from America including Alternaria, Cladosporium, Fusarium, 
Ochrocladosporium, Pseudofusarium and Leotiomyceta (Lucero et al. 2011). Salsola genus with 28 species is the most species-rich genus in Iran (Akhani 2006). We collected ten species of Salsola (site A: Salsola crassa 34\%-42\%, Salsola nitraria 96\%, Salsola incanescencs 74\%, site B: Salsola arbuscula 100\%, Salsola crassa 64\%, Salsola nitraria 78\%, Salsola incanescens 100\%, Salsola kerneri 69\%, Salsola tomentosa 100\%, Salsola yazdiana 76\%, Salsola kali 78\%, site C: Salsola $\mathrm{Sp}_{1 .} .66 \%$ and Salsola $\mathrm{Sp}_{2} .80 \%$ ). Because of the presence of underground saline water and low precipitation, there are well over half of Salsola in Kavir-e Yazd. Salsola can overcome to highstress condition by interaction with a wide range of endophyte fungi. Fungal species diversity shows by Shannon's index. In site A, Shannon's diversity ranged from 0.63-1.09. The Shannon's index showed Anabasis aphylla (1.09), Anabasis setifera (1.09) and Salsola crassa (1.09) had the highest fungal diversity (Table 1). The maximum of Shannon's diversity found in Kochia scoparia (1.6), Anabasis setifera (1.56) and Chenopodium album (1.56) in site B (Table 2). Site C showed the highest diversity among Chenopodium album (1.6) and Amaranthus blitum (1.6) (Table 3).

Table 2 Fungal taxonomy, number of endophyte isolates, root colonization rate (\%) and Shannon's index in site B of the studied plant species.

\begin{tabular}{|c|c|c|c|c|}
\hline $\begin{array}{l}\text { Plant species of Site B } \\
\text { (Kavir-e Yazd) }\end{array}$ & Fungal taxonomy & $\begin{array}{l}\text { Number of } \\
\text { isolates }\end{array}$ & $\begin{array}{l}\text { Colonization } \\
\text { rate }(\%)\end{array}$ & Shannon's (H) \\
\hline \multirow{2}{*}{ Salsola arbuscula } & Acremonium sp.2 & 1 & 100 & 0.63 \\
\hline & Fusarium sp.3 & 2 & & \\
\hline \multirow[t]{3}{*}{ Salsola crassa } & Aspergillus terreus & 2 & 64 & 1.05 \\
\hline & Fusarium sp.1 & 1 & & \\
\hline & Fusarium sp.5 & 2 & & \\
\hline \multirow[t]{3}{*}{ Salsola nitraria } & Curvolaria sp.1 & 2 & 78 & 1.04 \\
\hline & Fusarium solani & 1 & & \\
\hline & Fusarium sp.1 & 1 & & \\
\hline \multirow[t]{3}{*}{ Salsola incanescens } & Fusarium solani & 2 & 100 & 1.05 \\
\hline & Fusarium sp.1 & 2 & & \\
\hline & Penicillium sp. & 1 & & \\
\hline \multirow[t]{2}{*}{ Salsola kerneri } & Aspergillus awamiri & 2 & 69 & 0.63 \\
\hline & Fusarium oxysporum & 1 & & \\
\hline \multirow[t]{3}{*}{ Salsola tomentosa } & Bipolaris sp. & 1 & 100 & 1.04 \\
\hline & Fusarium brachygibbosum & 1 & & \\
\hline & Fusarium sp.4 & 2 & & \\
\hline \multirow[t]{2}{*}{ Salsola yazdiana } & Alternaria consortialis & 1 & 76 & 0.63 \\
\hline & Fusarium sp.1 & 2 & & \\
\hline \multirow[t]{2}{*}{ Seidllitzia florida } & Fusarium oxysporum & 1 & 52 & 0.63 \\
\hline & Fusarium sp.3 & 2 & & \\
\hline \multirow[t]{3}{*}{ Seidllitzia rosmarinus } & Fusarium sp.2 & 1 & 74 & 1.09 \\
\hline & Ulocladium sp. & 1 & & \\
\hline & Embellisia sp. & 1 & & \\
\hline \multirow[t]{2}{*}{ Kochia stellaris } & Curvolaria spicifera & 2 & 100 & 0.69 \\
\hline & Fusarium sp.6 & 2 & & \\
\hline \multirow[t]{5}{*}{ Kochia scoparia } & Aspergillus sp. 2 & 1 & 100 & 1.6 \\
\hline & Curvolaria sp.2 & 1 & & \\
\hline & Cladosporium sp. & 1 & & \\
\hline & Fusarium brachygibbosum & 1 & & \\
\hline & Penicillium sp. & 1 & & \\
\hline \multirow[t]{2}{*}{ Anabasis annua } & Aspergillus fumigatus & 2 & 100 & 0.69 \\
\hline & Fusarium sp.5 & 2 & & \\
\hline \multirow[t]{2}{*}{ Anabasis aphylla } & Fusarium brachygibbosum & 2 & 94 & 0.63 \\
\hline & Macrophomina phaseolina & 1 & & \\
\hline \multirow[t]{5}{*}{ Anabasis setifera } & Ascochyta sp. & 1 & 86 & 1.56 \\
\hline & Aspergillus terreus & 2 & & \\
\hline & Fusarium sp.2 & 1 & & \\
\hline & Fusarium sp.4 & 1 & & \\
\hline & Mycellia sterile & 1 & & \\
\hline
\end{tabular}


Table 2 Continued.

\begin{tabular}{|c|c|c|c|c|}
\hline $\begin{array}{l}\text { Plant species of Site B } \\
\text { (Kavir-e Yazd) }\end{array}$ & Fungal taxonomy & $\begin{array}{l}\text { Number of } \\
\text { isolates }\end{array}$ & $\begin{array}{l}\text { Colonization } \\
\text { rate }(\%)\end{array}$ & Shannon's (H) \\
\hline \multirow[t]{5}{*}{ Chenopodium album } & Acremonium sp.1 & 1 & 80 & 1.56 \\
\hline & Acremonium sp.2 & 1 & & \\
\hline & Fusarium sp.4 & 1 & & \\
\hline & Penicillium sp. & 2 & & \\
\hline & Mycellia sterile & 1 & & \\
\hline \multirow[t]{2}{*}{ Girginsonia oppositifflora } & Fusarium sp.4 & 2 & 94 & 0.63 \\
\hline & Penicillium sp. & 1 & & \\
\hline \multirow[t]{2}{*}{ Halothamnus subaphyllus } & Fusarium sp.3 & 3 & 58 & 0.56 \\
\hline & Mycellia sterile & 1 & & \\
\hline \multirow[t]{2}{*}{ Halimocnemis pilifera } & Acremonium sp.2 & 1 & 100 & 0.63 \\
\hline & Mycellia sterile & 2 & & \\
\hline \multirow[t]{3}{*}{ Suaeda aegyptica } & Acremonium sp.1 & 1 & 92 & 1.04 \\
\hline & Fusarium oxysporum & 2 & & \\
\hline & Mycellia sterile & 1 & & \\
\hline \multirow[t]{4}{*}{ Atriplex aucheri } & Aspergillus awamori & 1 & 100 & 1.27 \\
\hline & Aspergillus fumigatus & 2 & & \\
\hline & Fusarium oxysporum & 3 & & \\
\hline & Mycellia sterile & 1 & & \\
\hline \multirow[t]{3}{*}{ Atriplex leucoclada } & Fusarium sp.2 & 1 & 100 & 1.09 \\
\hline & Rhizoctonia sp. & 1 & & \\
\hline & Mycellia sterile & 1 & & \\
\hline \multirow[t]{3}{*}{ Chenopodium album } & Acremonium sp.1 & 1 & 82 & 1.33 \\
\hline & Gibberella tapsina & 1 & & \\
\hline & Fusarium sp.3 & 2 & & \\
\hline \multirow[t]{3}{*}{ Haloxylon persicum } & Acremonium sp.2 & 1 & 100 & 1.09 \\
\hline & Fusarium brachygibbosum & 1 & & \\
\hline & Mycellia sterile & 1 & & \\
\hline \multirow[t]{3}{*}{ Hammada salicornica } & Aspergillus calidoustus & 1 & 40 & 1.09 \\
\hline & Fusarium sp.1 & 1 & & \\
\hline & Fusarium sp.5 & 2 & & \\
\hline \multirow[t]{3}{*}{ Kochia indica } & Aspergillus fumigatus & 1 & 96 & 1.04 \\
\hline & Fusarium sp.2 & 1 & & \\
\hline & Mycellia sterile & 1 & & \\
\hline \multirow[t]{2}{*}{ Noaea mucronata } & Aspergillus terreus & 2 & 80 & 0.63 \\
\hline & Fusarium sp.4 & 1 & & \\
\hline \multirow[t]{2}{*}{ Salsola kali } & Aspergillus fumigatus & 2 & 78 & 0.63 \\
\hline & Fusarium sp.1 & 1 & & \\
\hline Spinacia oleracea & Aspergillus terreus & 1 & 10 & 0 \\
\hline Beta vulgaris & Fusarium sp.6 & 1 & 4 & 0 \\
\hline
\end{tabular}

For diversity comparison in three sites, we selected three plant species (Chenopodium album, Anabasis setifera and Atriplex aucheri) that there are in all three sites (Table 4). Shannon's and Fisher's Alpha indices illustrated that fungal diversity is different in three sites. According to Shannon's index, diversity of fungi in site C (2.45) is higher than that of site B (2.4) and site A (2.02). In addition Fisher's Alpha indicated that site $C$ had the most diversity (75.8), while Fisher's Alpha for site A and B is 18.48 and 13.98, respectively (Table 4). In previous section were explored that Colonization rate was the highest in site $\mathrm{A}$ and $\mathrm{B}$, while now illustrated that fungal diversity is the highest in site $\mathrm{C}$ (Table 4). The optimal growth condition for many fungi is the hot and moist climate (Suryanarayanan et al. 2002). However, to reduce damage in hard condition (site A and B), plants species tend to high colonize with a wide range of endophyte fungi (Jacobson et al. 2015). Melanin in the DSE may form complex with oxygen radical that formed during stress condition (Redman et al. 2002). Studies show that, dark septate endophytes seem to occur more frequently in temperate forests than that in temperate grassland ecosystems (Mandyam \& 
Jumpponen 2008). Status of root endophytes in tropical ecosystems varied ranging from $25-75 \%$ (Rains et al. 2003). In general, changes in annual temperature and precipitation can change soil condition which could affect frequency and diversity of root endophytes (Sieber \& Grünig 2013).

Table 3 Fungal taxonomy, number of endophyte isolates, root colonization rate (\%) and Shannon's index in site $\mathrm{C}$ of the studied plant species.

\begin{tabular}{|c|c|c|c|c|}
\hline $\begin{array}{l}\text { Plant species of Site } \\
\text { C(Khalij-e Gorgan) }\end{array}$ & Fungal taxonomy & $\begin{array}{l}\text { Number } \\
\text { of } \\
\text { isolates }\end{array}$ & $\begin{array}{l}\text { Colonization } \\
\text { rate }(\%)\end{array}$ & $\begin{array}{l}\text { Shannon's } \\
\text { (H) }\end{array}$ \\
\hline \multirow[t]{2}{*}{ Halocnemum strobilaceum } & Acremonium sp.1 & 1 & 50 & 0.69 \\
\hline & Bipolaris sp. & 1 & & \\
\hline \multirow[t]{2}{*}{ Salicornia herbacea } & Fusarium sp.1 & 1 & 90 & 0.63 \\
\hline & Fusarium sp.3 & 2 & & \\
\hline \multirow[t]{3}{*}{ Anabasis setifera } & Alternaria chlamydosporigena & 1 & 84 & 1.04 \\
\hline & Fusarium solani & 2 & & \\
\hline & Fusarium sp.2 & 1 & & \\
\hline \multirow[t]{2}{*}{ Salsola $S p_{1}$} & Acremonium sp.1 & 1 & 66 & 0.69 \\
\hline & Acremonium sp.2 & 1 & & \\
\hline \multirow[t]{3}{*}{ Salsola $S p_{2}$} & Curvolaria sp.1 & 1 & 80 & 1.09 \\
\hline & Fusarium sp.1 & 1 & & \\
\hline & Fusarium sp.2 & 1 & & \\
\hline \multirow[t]{5}{*}{ Chenopodium album } & Acremonium sp.2 & 1 & 66 & 1.6 \\
\hline & Curvolaria spicifera & 1 & & \\
\hline & Fusarium brachygibbosum & 1 & & \\
\hline & Fusarium sp.6 & 1 & & \\
\hline & Mycellia sterile & 1 & & \\
\hline \multirow[t]{5}{*}{ Amaranthus blitum } & Acremonium sp. 2 & 1 & 86 & 1.6 \\
\hline & Aspergillus terreus & 1 & & \\
\hline & Aspergillus sp.1 & 1 & & \\
\hline & Cladosporium sp. & 1 & & \\
\hline & Fusarium sp.4 & 1 & & \\
\hline \multirow[t]{4}{*}{ Atriplex aucheri } & Aspergillus fumigatus & 1 & 80 & 1.38 \\
\hline & Fusarium sp.1 & 1 & & \\
\hline & Fusarium sp.3 & 1 & & \\
\hline & Chaetomium sp. & 1 & & \\
\hline \multirow[t]{4}{*}{ Salicornia Persica } & Acremonium sp.1 & 1 & 90 & 1.33 \\
\hline & Fusarium oxysporum & 2 & & \\
\hline & Fusarium sp.3 & 1 & & \\
\hline & Fusarium sp.5 & 1 & & \\
\hline Spinacia oleracea & Fusarium sp.6 & 1 & 0 & 0 \\
\hline Beta vulgaris & Fusarium sp.4 & 1 & 10 & 0 \\
\hline
\end{tabular}

Table 4 Comparison of fungal species diversity (Shannon's) to compare plant species ( $\mathrm{a}, \mathrm{b}$ and $\mathrm{c}$ ) and comparison of fungal species diversity (Shannon's and Fisher's) to compare three sites.

\begin{tabular}{|c|c|c|c|c|c|c|c|c|c|}
\hline Site & & $\mathbf{A}$ & & & B & & & $\mathbf{C}$ & \\
\hline Plant species & $\mathrm{a}$ & $\mathrm{b}$ & $\mathrm{c}$ & $\mathrm{a}$ & $\mathrm{b}$ & $\mathrm{c}$ & $\mathrm{a}$ & $\mathrm{b}$ & $\mathrm{c}$ \\
\hline Shannon's (H) & 1.04 & 1.09 & 0.63 & 1.56 & 1.56 & 1.27 & 1.6 & 1.04 & 1.38 \\
\hline Isolate & 4 & 3 & 3 & 6 & 6 & 7 & 5 & 4 & 4 \\
\hline Fungi species & 8 & & & 12 & & & 12 & & \\
\hline Shannon's (H) & 2.02 & & & 2.40 & & & 2.45 & & \\
\hline Fisher's Alpha & 18.48 & & & 13.98 & & & 75.8 & & \\
\hline
\end{tabular}

a- Chenopodium album, b- Anabasis setifera, $c$ - Atriplex aucher

$A$ - Dasht-e Javar, B- Kavir-e Yazd, C- Khalij-e Gorgan

In this study, the highest number of isolated fungi was obtained for Fusarium genera in all three ecosystems, site A (51\%), site B (49\%), site C (57\%) (Fig. 3). Literature reveals that diversity 
of Fusarium species among plant species is remarkable. Fusarium species have adapted to a wide range of geographical sites, climatic conditions, ecological habitats, and host plants. Species of this polyphyletic genus have been documented to occur worldwide (Summerell et al. 2001). Researchers showed that Fusarium verticillioides can colonize about 1000 plant species, for example maize which is considered as a strategic crop. Fusarium genus plays important role in nutrient uptake in roots, but some of biotic or abiotic factors can change Fusarium's interaction with plants from mutualism to parasitism (Kuldau \& Yates 2000). Fusarium species are able to producing certain mycotoxins that can impact on animal and human health (Bacon \& Yates 2006).

Similarly, researchers found that Fusarium genus is present among fourteen isolate obtained from the roots of Saussurea involucrate (Lv et al. 2010). Species of Cylindrocarpon, Fusarium, Gibberella, Ilyonectria, and Neonectria and the Sebacinales are the most frequent and most widespread root endophytes after DSE fungi (Eshel \& Beeckman 2013). Already, many researchers reported more than 100 species of Fusarium, Gaeumannomyces, Gibberella, Harpophora, Microdochium, Monographella, and Periconia from roots of winter wheat (Sieber \& Grünig 2013). Aspergillus were isolated from all sites. This genus made up the second most frequent group for all three sites: site A (20\%), site B (18\%), site C (9\%) (Fig. 3). On the other hand, in both temperate and arid ecosystems, Aspergillus is of secondary importance after Fusarium, Aspergillus is a nonclavicipitaceous endophyte shown to be effective producers of bioactive metabolites. Some members of Aspergillus and Fusarium are capable of producing anti-cancer metabolites like podophyllotoxin, rohitukine and camptothecin (Zhao et al. 2010). Dematiaceous genera, which include many Alternaria, Ulocladium, Cladosporium, Chaetomium, Curvularia, Bipolaris, Macrophomina and Embellisia were represented in site A (7\%), B (12\%) and C (14\%) (Fig. 3). Study of root endophytic fungi in herbaceous plants shows that dematiaceous fungi structures colonized 30 of 72 examined plants (Sieber \& Grünig 2013). For the first time, in Southern Australia isolated Fusarium sp., Alternaria chlamydospora as endophytes from Atriplex vesicaria plant (Sieber \& Grünig 2013). Penicillium and Rhizoctonia genera were not obtained in site C (Khalij-e Gorgan), while Acremonium genus had 17\% frequency. Symbioses of plants with Acremonium sp. can yield more resistance against insects, but some species, in particular Acremonia can cause disease and low productivity in grazing animals (Sieber \& Grünig 2013). Aspergillus sp. (four), Acremonium sp. (five), Cladosporium sp. (three), Curvularia sp. (one), Fusarium sp. (eleven), Microdochium sp. (six) and P. macrospinosa (49) are endophytic fungi isolated in an annually burned tallgrass prairie (Mandyam et al. 2010). In addition, we isolated different kinds of Alternaria sp., Bipolaris sp. and Curvularia sp. that colonized the roots with typical DSE structures. During the survey in this study, we observed sharp difference not only in fungi frequency but also in biodiversity of endophytic fungi species isolated from plants in different sites. The species composition of major endophytic fungi was generally similar when a single host plant species was examined from geographically separated arid ecosystems. Site A and site B in arid region have similar humidity pattern. Therefore, they show the same fungal distribution. In contrast, site $\mathrm{C}$ as a temperate region had different fungal biodiversity and colonization potential.

\section{Alternaria at three sites}

In the present study, Alternaria genus was isolated one species from each site (Alternaria alternata (site A), Alternaria consortialis (site B) and Alternaria chlamydosporigena (site C)). Alternaria genus is the best candidate of fungi that growth in harsh ecosystem plants. Many of studies introduced Alternaria as a main fungus in halophytes of the Chenopodiaceae (Crabtree \& Gessner 1982, Petrini \& Fisher 1986, Muhsin \& Booth 1987). Alternaria capable to produce a great dark pigment (melanin). Researchers suggested that mycelia containing melanin could absorb more sunlight and all types of electromagnetic radiation than other mycelia. In fact, melanin has the same behavior to chlorophyll (Dadachova \& Casadevall 2008). However, Alternaria could be an important fungal species for further studies. In this study we address the phylogenetic of Alternaria species. In the phylogenetic tree, three species of Alternaria from three sites were divided into three distinct groups (Fig. 5). Alternaria consortialis (accession no. MG674227) isolated from Salsola 
yazdiana in site B. This shrubby species is endemic to central and south-west areas of Iran (Assadi 2001). It grows on sand dunes and saline plains. Conidia and conidiophores of Alternaria consortialis has been shown in Fig. 4a. Alternaria alternata (accession No. MG674226) isolated from Cornulaca leucacanthahealthy plants in site A. Conidia and conidiophores of Alternaria alternata has been shown in Fig. 4b. Alternaria chlamydosporigena (accession No. MG817369) isolated from Anabasis setifera in site C. Conidia and conidiophores of Alternaria chlamydosporigena has been shown in Fig. 4c.
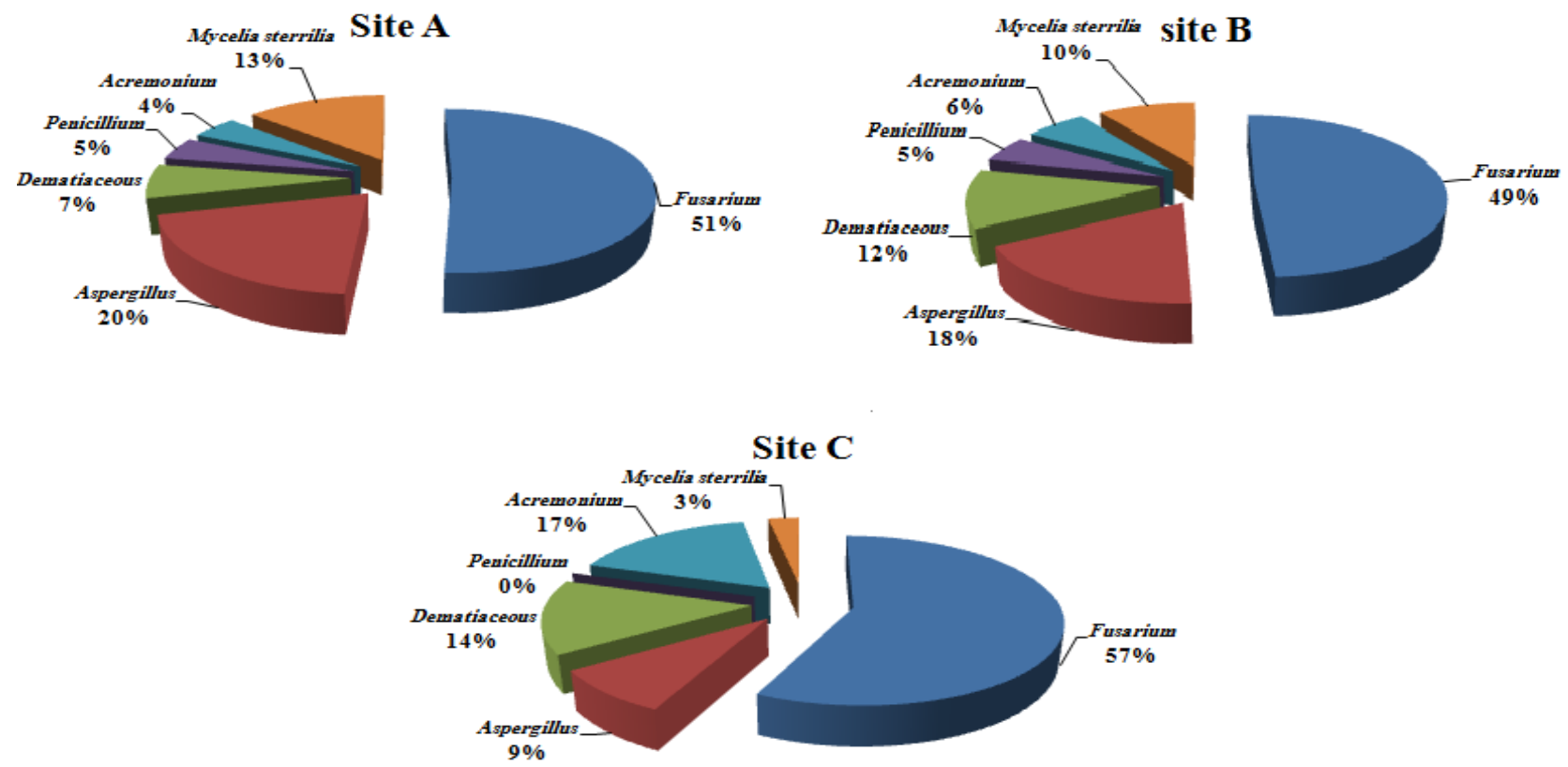

Figure 3 - Frequency pattern and biodiversity of endophytic fungi in site A (Dasht-e Javar), site B(Kavir-e Yazd) and site C (Khalij-e Gorgan).

The GAPDH gene sequences of Alternaria consortialis (site B) and that of A. consortialis strain PAV.ML.1072 (accession no. KF993386.1) shared 97\% identities and A. alternata (site A) and that of A. alternata strain CBS 130263 (accession no. KP124242.1) shared 97\% identities (Fig. 5). This is the first report of Alternaria consortialis, A. alternata and A. chlamydosporigena as endophytic fungi from these hosts in the world. Previously, Alternaria alternata and A. tenuissima were isolated from Salicornia perennis in south and east coast of England that was the first report of endophytic fungi from Chenopodiaceae (Petrini \& Fisher 1986). Cactus species in Arizona deserts had high frequency of colonization by pigmented fungi such as Alternaria and Phoma (Suryanarayanan et al. 2005). In new research, Alternaria alternate and Alternaria franseriae were reported as endophytic fungi from two spices of Chenopodiaceae (Salsola collina and Suaeda salsa) in deserts of China (Sun et al. 2012).

\section{Effect of climate and soil condition on the isolated fungi}

Our isolation experiment from roots of Chenopodiaceae species at three sites showed that there are many differences among endophytic fungi distributions in ecosystems. Totally, in this study we observed that root colonization of many Chenopodiaceae species in arid region is more than that in moist regions. For example, Atriplex aucheri species colonization rate is $100 \%$ in site B (Kavir-e Yazd) while this parameter is $88 \%$ in site A and $80 \%$ in site C. In contrast, the diversity of fungi is higher in moist climate than in arid regions (Table 4). Diversity of endophytic fungi in tropical ecosystems is still unclear (Hawksworth 2004). However, diversity of endophytic fungi in dry tropical forest is much less than in wet tropical forest. In addition, we investigated similarity of the fungal pattern in three sites by Jaccard index. Table 5 shows three sites shared few fungal species. The Jaccard similarity index ranged from 0 to 1 , where 1 explored that two groups are the 
same. In this study, all three sites had low similarity or high Jaccard's distance. However, Jaccard index for similarity of site A and B was 0.26 , while for site $\mathrm{A}$ and $\mathrm{C}$ was 0.17 and site $\mathrm{B}$ and $\mathrm{C}$ was o.21. This result shows that site A and B have the highest similarity with together.

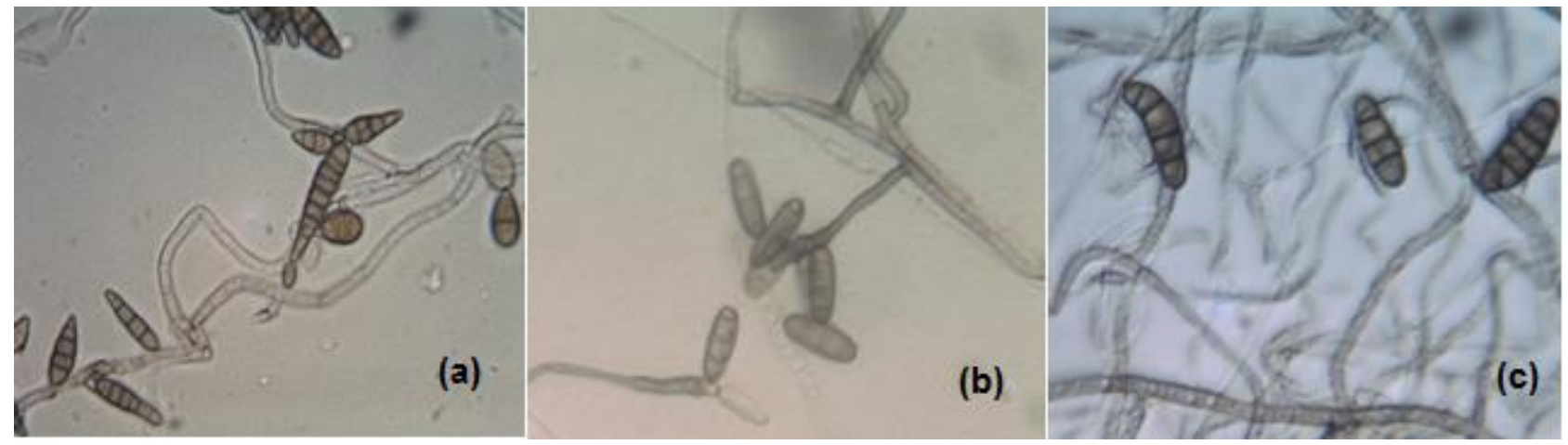

Figure 4 - a Conidia and conidiophores of Alternaria consortialis. b Alternaria alternate. c Alternaria chlamydosporigena.

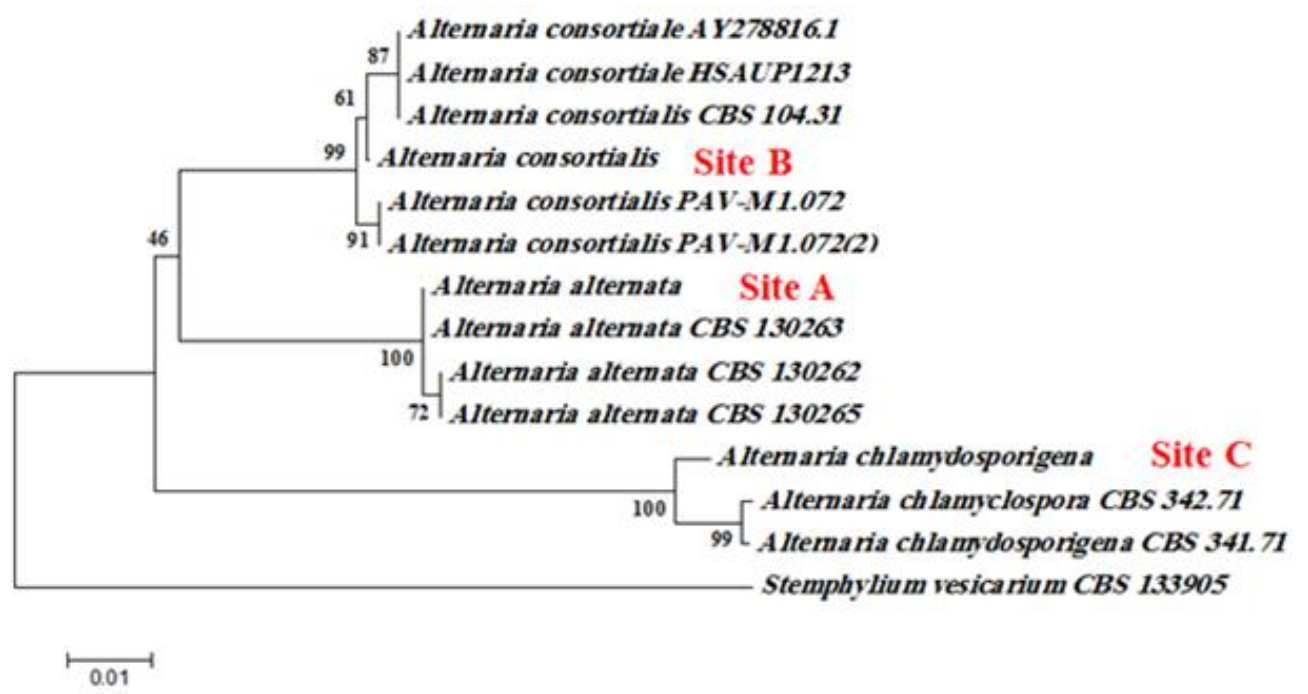

Figure 5 - Neighbor-joining tree (MEGA software) inferred from glyceraldehyde 3-phosphate dehydrogenase gene sequences of Alternaria consortialis (site B) isolate, Alternaria alternata (site A) isolate and Alternaria chlamydosporigena isolate (site C). Stemphylium vesicarium was used as outgroup. Numbers of the branches indicate the percentage of bootstrap value after 1,000 replications.

Table 5 Comparison of Jaccard index among sampling sites base on three plant species (a, b, c see Table 4)

\begin{tabular}{lccc}
\hline Index & Site A cf. Site B & Site A cf. Site C & Site B cf. Site C \\
\hline Jaccard & 0.26 & 0.17 & 0.21 \\
& & & \\
\hline
\end{tabular}

The differences in colonization pattern and diversity could be related to difference in phytogeographic position, climatic and soil condition. Some chemical and physical properties of soil sampled from around the roots of some the studied plants have been shown in Table 6 . In three ecosystems $\mathrm{pH}$ values varied between 7.1 in site $\mathrm{C}$ to 8.5 in site $\mathrm{B}$ (Table 6). Variability in soil $\mathrm{pH}$ may influence the surrounding soil and change endophyte fungi in three ecosystems. Some of fungi 
prefer acidic soils while others prefer alkaline soil (Sieber 2007). According to statistical analysis, there is a positive correlation between soil $\mathrm{pH}$ and Cryptosporiopsis radicicola and Cylindrocarpon didymium also a negative correlation between soil pH and DSE (Sieber \& Grünig 2013). Some Cylindrocarpon species are well known to prefer alkaline conditions but $P$. fortinii as a DSE prefer to infect roots that grew in acidic soils (Sieber \& Grünig 2013). Although were reported that colonization of DSE occur in roots with $\mathrm{pH}$ values ranging from 3.5 to 4.5 (Ahlich et al. 1998), in this study we found that DSEs can occur in roots with $\mathrm{pH}$ values ranging from 7 to 8 in high altitude (1230-2000m) to low altitude (13m).

Table 6 Some chemical and physical properties of soil sampled from around the roots of some the studied plants.

\begin{tabular}{ccccccccccccc}
\hline Plant & \multicolumn{3}{c}{ Atriplex } & \multicolumn{4}{c}{ Chenopodium } & \multicolumn{3}{c}{ Anabasis } & \multicolumn{3}{c}{ Salsola } \\
\hline site & A & B & C & A & B & C & A & B & C & A & B & C \\
$\mathbf{p H}$ & 7.8 & 7.8 & 7.1 & 7.8 & 8.4 & 7.8 & 7.6 & 8.5 & 7.7 & 7.7 & 8.4 & 7.6 \\
$\mathbf{E C}^{ \pm}$ & 1.98 & 1.4 & 22 & 2.5 & 2.7 & 12 & 4.55 & 3.4 & 11 & 3.8 & 4.5 & 23 \\
$\left(\mathbf{d S ~ m}^{-1}\right)$ & & & & & & & & & & & & \\
$\mathbf{O M}^{\neq}$ & 2.00 & 0.7 & 3.00 & 0.9 & 1.3 & 3.2 & 0.9 & 0.7 & 3.9 & 0.8 & 0.9 & 2.5 \\
$(\boldsymbol{\%})$ & & & & & & & & & & & & \\
Texture $^{\epsilon}$ & SCL & SCL & SiL & L & SCL & SiL & SCL & CL & SiCL & C & SCL & SiCL
\end{tabular}

\footnotetext{
${ }^{ \pm} \mathrm{EC}:$ Electrical Conductivity

$\neq$ OM: Organic Matter

${ }^{€}$ S: Sand; C: Clay; Si: Silt; L: Loam
}

Recently, researchers reported that roots colonized by $I$. radicicola in alkaline soils in low altitude, but DSE in acidic soil (peat bog in low altitude) and as well as in alkaline soil in high altitude with high frequency (Sieber \& Grünig 2013). Some of fungi like Cryptosporiopsis abietina (perhaps conspecific with C. radicicola) and I. radicicola preferred a neutral environment (Eshel \& Beeckman 2013). Another important factor that influences on frequency and colonization of root endophytes is soil EC representing soil salinity. At the present study, the highest electrical conductivity obtained at site $\mathrm{C}\left(23 \mathrm{dS} \mathrm{m} \mathrm{m}^{-1}\right)$ (Table 6). Although, site A and site B showed lower salinity (1.4-4.5 $\mathrm{dS} \mathrm{m}^{-1}$ respectively) compared to site $\mathrm{C}$, many species of endophytic fungi can be isolated from Chenopodiaceae family that are capable to grow there (site A and B). The halophytic vegetation of site A and B is species-rich compared to site C including species of Salsola, Seidllitzia, Kochia, Anabasis, Chenopodium, Halimocnemis and Haloxylon that have been colonized by some kind of endophytic fungi like DSE. DSEs may replace AM in stressed environments. This hypothesizes supported by the findings of some researchers that observed two Dematiaceous endophytes, a Coelomycete and a Rhizoctonia-like fungus, were frequently isolated from roots of some mangroves and saline resistant plants growing in the sea bound delta region of west Bengal (Sieber \& Grünig 2013). The organic matter content in site A and B (0.7-2\%) is lower than those of site C (2.5-3.9\%) (Table 6). Soil with low organic matter is favorable for DSE fungi. Roots growing in alpine soils with little organic matter colonize by DSE and those growing in habitats with more organic matter colonize by arbuscular mycorrhizal fungi (Newsham 2011). Three alpine species of the Fabaceae (Astragalus alpinus L., A. vexilliflexus E. Sheld., Oxytropis jordalii A.E. Porsild), a family that is usually endomycorrhizal in other habitats, lacked AM but were colonized by DSE (Sieber \& Grünig 2013). Trifolium repens L. and Plantaga asiatica L. colonized by DSE. Frequency of colonization by DSE had a positive correlation with sunlight and moisture but had a negative correlation with frequency of arbuscular mycorrhiza, nitrogen, phosphorus potassium, or soil organic matter content and temperature (Lingfei et al. 2005). 


\section{Conclusion}

The distribution of Chenopodiaceae species and their symbiosis with endophytic fungi in Iran depends on climate. Changing environmental conditions can influence the level of host susceptibility. The evaluation of available data shows that frequency of endophytic fungi in Chenopodiaceae family in Iran is not only related to the species type, but also in larger scale they can be different according to change in the ecosystem. The highest colonization rate $(100 \%)$ was observed in site B while, the fungal diversity of the sampled was low measured using Shannon's and Fisher's Alpha indices. However, fungal diversity was high in temperate region (site C). Results of this study confirmed that status of endophytic fungi in Chenopodiaceae family from arid soil (site A and B) and temperate soil (site C) is in the order of Fusarium>Aspergillus > Dematiaceous $>$ Penicillium $>$ Acremonium $>$ Rhizoctonia $>$ Mycelia sterilia. There was a high Jaccard's distance between three sites that indicates the infection and colonization of roots by endophytic fungi are affected by various factors, including sunlight intensity, moisture, climate, altitude and physical and chemical properties of soil but more studies are needed to illustrate impact of season and plant age on endophytic fungi in other parts of plant because fungal composition varies temporally across months and seasons.

\section{Acknowledgment}

We are grateful to Dr. Akbarzadeh in Agricultural Research, Education and Extension of Mazandaran and Mr. Mirhosseini in Agricultural Research, Education and Extension of Yazd for their help in identification and collection of Chenopodiaceae species. This work was supported by Bu- Ali- Sina University.

\section{References}

Ahlich K, Rigling D, Holdenrieder O, Sieber TN. 1998 - Dark septate hyphomycetes in Swiss conifer forest soils surveyed using Norway-spruce seedlings as bait. Soil Biology and Biochemistry 8, 1069-1075.

Akhani H. 2003 - Salicornia persica Akhani (Chenopodiaceae), a remarkable new species from Central Iran. na. 607-612.

Akhani H. 2006 - Biodiversity of halophytic and sabkha ecosystems in Iran. Sabkha ecosystems. Springer 71-88.

Akhani H. 2011 - Halophytic vegetation of Iran: towards a syntaxonomical classification. Annali di botanica $4,65-82$.

Assadi M. 2001 - Chenopodiaceae. Flora of Iran. 38, 260-261.

Bacon CW, Yates IE. 2006 - Endophytic root colonization by Fusarium species: histology, plant interactions, and toxicity. Microbial root endophytes. Springer 133-152.

Barrow J, Aaltonen R. 2001 - Evaluation of the internal colonization of Atriplex canescens (Pursh) Nutt. roots by dark septate fungi and the influence of host physiological activity. Mycorrhiza 4, 199-205.

Boldt-Burisch K, Naeth MA. 2017 - Early colonization of root associated fungal communities on reclamation substrates at a diamond mine in the Canadian Sub-Arctic. Applied Soil Ecology $110,118-126$.

Campanile G, Ruscelli A, Luisi N. 2007 - Antagonistic activity of endophytic fungi towards Diplodia corticola assessed by in vitro and in planta tests. European Journal of Plant Pathology 3, 237-246.

Crabtree SL, Gessner RV. 1982 - Growth and Nutrition of the Salt-Marsh Fungi Pleospora gaudefroyi and Camarosporium roumeguerii. Mycologia 640-647.

Dadachova E, Casadevall A. 2008 - Ionizing radiation: how fungi cope, adapt, and exploit with the help of melanin. Current opinion in microbiology 6, 525-531.

De Bary A. 1866 - Morphologia und physiologie der pilze, Flechten und Myxomyceten. Leipzig, Germany: Engelmann. 
Denison RF, Bledsoe C, Kahn M, O'Gara F et al. 2003 - Cooperation in the rhizosphere and the "free rider" problem. Ecology 4, 838-845.

Guo L D, Hyde KD, Liew EC. 2001 - Detection and taxonomic placement of endophytic fungi within frond tissues of Livistona chinensis based on rDNA sequences. Molecular Phylogenetics and Evolution 1, 1-13.

Guo LD, Huang GR, Wang Y, He WH et al. 2003 - Molecular identification of white morphotype strains of endophytic fungi from Pinus tabulaeformis. Mycological Research 6, 680-688.

Eshel A, Beeckman T. 2013 - Plant roots: the hidden half. CRC Press.

Hamim A, Miché L, Douaik A, Mrabet R et al. 2017 - Diversity of fungal assemblages in roots of Ericaceae in two Mediterranean contrasting ecosystems. Comptes Rendus Biologies 4, 226237.

Hawksworth DL. 2004 - Fungal diversity and its implications for genetic resource collections. Stud Mycol 50, 9-18.

Hirrel MC, Mehravaran H, Gerdemann JW. 1978 - Vesicular-arbuscular mycorrhizae in the Chenopodiaceae and Cruciferae: do they occur? Canadian Journal of Botany 22, 2813-2817.

Hyde KD, Soytong K. 2008 - The fungal endophyte dilemma. Fungal Divers 163, e73.

Jacobson K, van Diepeningen A, Evans S, Fritts R et al. 2015 - Non-rainfall moisture activates fungal decomposition of surface litter in the Namib Sand Sea. PLoS One 5, e0126977.

Kandalepas D, Stevens KJ, Shaffer GP, Platt WJ. 2010 - How abundant are root-colonizing fungi in Southeastern Louisiana's degraded marshes? Wetlands 2, 189-199.

Kannan K, Kumar DM, Ramya P, Nika SM et al. 2014 - Diversity of Endophytic Fungi from Salt Tolerant Plants. 6, 4084- 4088.

Kuldau GA, Yates IE. 2000 - Evidence for Fusarium endophytes in cultivated and wild plants. Microbial endophytes 85-117.

Lingfei L, Anna Y, Zhiwei Z. 2005 - Seasonality of arbuscular mycorrhizal symbiosis and dark septate endophytes in a grassland site in southwest China. FEMS Microbiology Ecology 3, 367-373.

Lucero ME, Unc A, Cooke P, Dowd S, Sun S. 2011 - Endophyte microbiome diversity in micropropagated Atriplex canescens and Atriplex torreyi var griffithsii. PLoS One 63, e17693.

Lv YL, Zhang FS, Chen J, Cui JL. 2010 - Diversity and antimicrobial activity of endophytic fungi associated with the alpine plant Saussurea involucrata. Biological and Pharmaceutical Bulletin 8, 1300-1306.

Mandyam K, Jumpponen A. 2008 - Seasonal and temporal dynamics of arbuscular mycorrhizal and dark septate endophytic fungi in a tallgrass prairie ecosystem are minimally affected by nitrogen enrichment. Mycorrhiza 3, 145-155.

Mandyam K, Loughin T, Jumpponen A. 2010 - Isolation and morphological and metabolic characterization of common endophytes in annually burned tallgrass prairie. Mycologia 4, 813-821.

Masumi S, Mirzaei S, Zafari D, Kalvandi R. 2015 - Isolation, identification and biodiversity of endophytic fungi o Thymus. Progress in Biological Sciences 1, 43-50.

Muhsin TM, Booth T. 1987 - Fungi associated with halophytes of an inland salt marsh, Manitoba, Canada. Canadian journal of botany 6, 1137-1151.

Narisawa K. 2017 - The dark septate endophytic fungus Phialocephala fortinii is a potential decomposer of soil organic compounds and a promoter of Asparagus officinalis growth. Fungal Ecology 28, 1-10.

Narisawa K, Kawamata H, Currah RS, Hashiba T. 2002 - Suppression of Verticillium wilt in eggplant by some fungal root endophytes. European Journal of Plant Pathology 2, 103-109.

Newsham KK. 2011 - A meta - analysis of plant responses to dark septate root endophytes. New Phytologist 3, 783-793.

Petrini O. 1991 - Fungal endophytes of tree leaves. Microbial ecology of leaves. Springer 179-197. 
Petrini O, Fisher PJ. 1986 - Fungal endophytes in Salicornia perennis. Transactions of the British Mycological Society 4, 647-651.

Promputtha I, Jeewon R, Lumyong S, McKenzie EHC, Hyde KD. 2005 - Ribosomal DNA fingerprinting in the identification of non sporulating endophytes from Magnolia liliifera (Magnoliaceae). Fungal Diversity.

Promputtha I, Lumyong S, Dhanasekaran V, McKenzie EHC et al. 2007 - A phylogenetic evaluation of whether endophytes become saprotrophs at host senescence. Microbial ecology 4, 579-590.

Pugh G, Williams GM. 1968 - Fungi associated with Salsola kali. Transactions of the British Mycological Society 51, 389-396.

Purahong W, Hyde KD. 2011 - Effects of fungal endophytes on grass and non-grass litter decomposition rates. Fungal Diversity 1, 1-7.

Rains KC, Nadkarni NM, Bledsoe CS. 2003 - Epiphytic and terrestrial mycorrhizas in a lower montane Costa Rican cloud forest. Mycorrhiza 5, 257-264.

Redman RS, Dunigan DD, Rodriguez RJ. 2001 - Fungal symbiosis from mutualism to parasitism: who controls the outcome, host or invader? New Phytologist 3, 705-716.

Redman RS, Sheehan KB, Stout RG, Rodriguez RJ, Henson JM. 2002 - Thermotolerance generated by plant/fungal symbiosis. Science 298, 1581-1581.

Rivera-Orduña FN, Suarez-Sanchez RA, Flores-Bustamante ZR, Gracida-Rodriguez JN, FloresCotera LB. 2011 - Diversity of endophytic fungi of Taxus globosa (Mexican yew). Fungal Diversity $1,65-74$.

Rodriguez RJ, Henson J, Van Volkenburgh E, Hoy M et al. 2008 - Stress tolerance in plants via habitat-adapted symbiosis. The ISME journal 4, 404-416.

Rodriguez R J, White Jr J F, Arnold A E, Redman A R A. 2009 - Fungal endophytes: diversity and functional roles. New phytologist 2, 314-330.

Safari Sinegani AA, Elyasi Yeganeh M. 2017 - The occurrence of arbuscular mycorrhizal fungi in soil and root of medicinal plants in Bu-Ali Sina garden in Hamadan, Iran. Biological Journal of Microorganism 5, 43-59.

Schulz B, Boyle C, Draeger S, Römmert AK, Krohn K. 2002 - Endophytic fungi: a source of novel biologically active secondary metabolites. Mycological Research 9, 996-1004.

Sharma BB, Jha D. 2017 - Arbuscular mycorrhiza and dark septate fungal associations in medicinal and aromatic plants of Guwahati. Journal of Microbiology and Biotechnology Research 1, 212-222.

Shen M, Zhao DK, Qiao Q, Liu L et al. 2015 - Identification of glutathione S-transferase (gst) genes from a dark septate endophytic fungus (Exophiala pisciphila) and their expression patterns under varied metals stress. PLoS One 4, e0123418.

Sieber TN. 2007 - Endophytic fungi in forest trees: are they mutualists? Fungal Biology Reviews 2, 75-89.

Sieber TN, Grünig CR. 2006 - Biodiversity of fungal root-endophyte communities and populations, in particular of the dark septate endophyte Phialocephala fortinii sl. Microbial root endophytes. Springer 107-132.

Sieber TN, Grünig CR. 2013 - Fungal root endophytes. In Plant Roots - The Hidden Half, ed. A Eshel, T Beeckman, 38.1-38.49. Boca Raton, FL, USA: CRC Press, Taylor \&amp; Francis Group.

Stone J, Polishook J, White J. 2004 - Biodiversity of fungi: inventory and monitoring methods. Elsevier Academic Press: New York,USA

Sonjak S, Udovič M, Wraber T, Likar M, Regvar M. 2009 - Diversity of halophytes and identification of arbuscular mycorrhizal fungi colonising their roots in an abandoned and sustained part of Sečovlje salterns. Soil Biology and Biochemistry 9, 1847-1856.

Summerell BA, Leslie JF, Backhouse D, Bryden WL, Burgess LW. 2001 - Fusarium: Paul E. Nelson Memorial Symposium. In Fusarium: Paul E. Nelson Memorial Symposium. American Phytopathological Society (APS Press). 
Sun Y, Wang Q, Lu X, Okane I, Kakishima M. 2012 - Endophytic fungal community in stems and leaves of plants from desert areas in China. Mycological progress 3, 781-790.

Suryanarayanan T, Murali T, Venkatesan G. 2002 - Occurrence and distribution of fungal endophytes in tropical forests across a rainfall gradient. Canadian Journal of Botany 8, 818826.

Suryanarayanan TS, Wittlinger SK, Faeth SH. 2005 - Endophytic fungi associated with cacti in Arizona. Mycological Research 5, 635-639.

Upson R, Newsham KK, Bridge P, Pearce DA, Read D. 2009 - Taxonomic affinities of dark septate root endophytes of Colobanthus quitensis and Deschampsia antarctica, the two native Antarctic vascular plant species. Fungal Ecology 4, 184-196.

Van Reeuwijk L P. 1993 - Procedures for soil analysis (No. 9). International Soil Reference and Information Centre.

You YH, Yoon H, Kang SM, Shin JH et al. 2012 - Fungal diversity and plant growth promotion of endophytic fungi from six halophytes in Suncheon Bay.Journal of microbiology and biotechnology 11, 1549-1556.

Zhao J, Zhou L, Wang J, Shan T et al. 2010 - Endophytic fungi for producing bioactive compounds originally from their host plants. Curr Res, Technol Educ Trop Appl Microbiol Microbial Biotechnol 1, 567-576. 